\title{
Impact Assessment of Tourism Construction in Cuba
}

\author{
Lourdes Ruiz Gutiérrez \\ International University of Ecuador, Quito, Ecuador \\ Email: Iruiz@internacional.edu.ec
}

Received 15 February 2015; accepted 4 March 2015; published 9 March 2015

Copyright (C) 2015 by author and Scientific Research Publishing Inc.

This work is licensed under the Creative Commons Attribution International License (CC BY). http://creativecommons.org/licenses/by/4.0/

c) (i) Open Access

\section{Abstract}

This paper discusses a methodology for the environmental assessment of tourist facilities located in Cuban coastal zones in which the general aspects of the process are discussed, defined, and characterized, and examines the main processes that occur as a result of the negative impacts of construction activities. It establishes the theoretical conceptual framework underlying the research and includes a detailed analysis and processing of a sample of tourism projects located in coastal ecosystems. The methodology is complemented by results that include proposed strategic lines of action and a plan for managing negative environmental impacts throughout the life cycle of tourist facilities through prevention, correction and mitigation measures. It ends with conclusions and recommendations to guide tourism development toward environmental sustainability.

\section{Keywords}

\section{Environmental Impact, Tourist Facilities, Coastal Ecosystems, Construction}

\section{Introduction}

Man has developed much of what exists in the world through industrialization, and the construction industry has played an important role in this transformation. However, we are far from implementing all the fundamental concepts required by the environment, according to the ecological impact of the incorrect application of construction technologies [1].

Globally the construction industry is a major contributor to socio-economic development and also a major user of energy and natural resources [2]. The construction industry consumes $40 \%$ of the materials entering the global economy and generates $40 \%$ - $50 \%$ of the global output of greenhouse gases and the agents of acid rain [3].

International tourism is projected to nearly double by 2030. In 2012, international tourism arrivals reached 
one billion for the first time, up from 25 million in 1950, 277 million in 1980 and 528 million in 1995 [4]. Travel and tourism in particular, as a form of entertainment or leisure [5], has a long history leading up to the 20th century when tourism developed into a multibillion dollar industry that spans virtually all countries [6], at the local, national and international levels [7].

Tourist facilities in coastal ecosystems often cause undesirable environmental impacts, also known as negative environmental impacts, and have severely affected natural vegetation, wildlife habitats, landscapes, soils and wetlands as a result of construction activities. The widespread development and use of quarries, excessive clearing of vegetation, filling of lakes, and other actions that cause severe damage to the environment can be avoided using design and technological measures that are appropriate for the valuable resources where it takes place [8].

Most tourist facilities that have been built do not include environmental and landscaping considerations in their planning and forecasting. This situation is due to ignorance or lack of environmental consciousness about how to intervene in coastal areas with high ecological fragility and sensitivity without causing severe environmental impacts, and a lack of integration of the conceptual ideas to harmonize necessary tourism development with sustainable approaches and practices.

The regional level has been recognized as a good scale for implementing actions towards sustainable development [9]. In this vein, one of the purposes of this research is to propose a methodology for analyzing construction activities that cause negative environmental impacts in tourism investments and propose strategic lines of action for managing those activities based on sustainability without stopping development.

The definition of the field of application of the research object relates to the variation of tourism construction activities on different geographical areas and ecosystems, and the need for integral management of ecological, social, economic and technological aspects of environmental impacts; the following research question is formulated as a problem to be solved:

- What are the necessary definitions, existing gaps and key actions that need to be considered in the methodology of environmental assessment of coastal areas for tourist facilities in coastal ecosystems in order to introduce sustainable development approaches?

\subsection{Objectives}

1) To specify the general concepts and considerations of tourist facilities that will permit an integrated impact analysis consistent with environmentally sustainable development approaches.

2) To design an appropriate methodology for evaluating the direct actions of construction technologies that cause negative environmental impacts, and propose management actions for tourism projects in sensitive coastal ecosystems.

\subsection{System of Hypothesis}

- If tourist facilities are to be rational long-term economic (environmental costs) initiatives that are culturally (identity) and socially (quality of life) appropriate, respectful of the protection of the natural environment and technologically appropriate, methodological tools that lead to sustainability will be required.

- Sustainable development can be achieved if existing management tools are improved, such as environmental assessment and other procedures to coordinate, act upon and effectively integrate environmental concepts with technological, sociocultural and economic concepts.

\section{Materials and Methods}

The analysis was carried out from the general to the particular, discussing domestic and foreign experience and the opinions of experts and of the author herself, and was organized according to the following tasks:

- Analysis of the current situation, statement of the problem, and definition of the objectives, assumptions and methodology employed.

- Definition of the concepts and general aspects of environmental assessment based on the characteristics of the process and its relationship with sustainable development approaches (dimensions, objectives, means, and tools).

- Analysis and discussion of the stages of environmental assessment and its relationship to the life cycle of 
tourist facilities in coastal ecosystems.

- Analysis of the problem of tourist facilities and planning, and their relationship to the proposed hypotheses.

- Analysis and discussion of effective tools for the sustainable development of tourist facilities.

- Final conclusions.

A critical analysis of the environmental process of tourism projects and construction research provided the necessary information for identifying existing problems, their causes and proposing theoretical and methodological solutions.

The selection of tourism projects has several characteristics, such as multi-objectives, multi-attributes and multi-criteria. These criteria can be considered relative to society, economy, finance, human resources, environment, market, and politics [10].

The application of environmental analysis methods to the field of architecture and construction design allowed us to study and evaluate the actions involved in planning, designing and executing projects, and using and abandoning or recycling buildings in order to identify, predict, interpret and communicate the negative environmental impacts caused by these activities under current conditions to achieve a social model with sustainability approaches for tourism. The table below shows the methods and techniques most commonly used in environmental studies (Table 1 ).

Methods involving matrices are often used in environmental analyses and studies. It is also common to use the compared scenario method because it allows the comparison of projects in selected ecosystems or different environmental scenarios. Compared environmental scenarios are the most appropriate qualitative method for comparing observation projects in different ecosystems and geographic regions. This method is based on monitoring and assessing changes in the environment [11], over a fixed period, and allows other complementary analyses to be incorporated, such as the matrix methods mentioned.

\section{Results}

Tourism development plans were presenting a development stereotype that would be in conflict with important biological resources, and not in agreement with the evolution of the tourism market in the Caribbean. Tourism is recognized as an important source of foreign currencies in Cuba. Given the current status of economy, and the good health of coastal ecosystems, tourism based on the environment is the compatible option of development [12].

In the sample studied, $100 \%$ of the available background information from environmental assessments of nominal tourism investments was selected over a 4 year period. Projects involving hotel accommodations, villa resort, services, and recreation in new tourism development areas of the principal tourism construction projects

Table 1. Methods and techniques commonly used in environmental studies.

\begin{tabular}{cc}
\hline \multicolumn{1}{c}{ Methods } & Techniques \\
\hline Statistical information processing & Statistical: non-parametric. \\
Statistical: parametric
\end{tabular}


were analyzed (Table 2).

In order to establish an analytical process based on deductive and comparative statistical tools to permit the identification of construction activities that negatively impact each ecosystem most significantly, statistical processing was performed on projects selected based on non-parametric statistics. Principal component analysis was used, due to the characteristics of the study variables (discrete, qualitative and measured on an ordinal scale). Computer modelling has also shown its usefulness in theoretically predicting environmental parameters under different conditions and challenges [13].

Before applying the method, the correlation coefficients were calculated to reduce the dimensions of the problem and apply the above test; it is the recommended method for data tables with calculated qualitative components that correspond to the nature of the variables, since these coefficients can be used to construct correlation matrices for developing the main components. Ruiz, (1999) [14], suggest that several types of correlation coefficients can be applied. However, when there are more than 20 variables, it is recommended that the Spearman range coefficient be applied using automated means. With knowledge of the functional relationship matrix and the project sequence chart, the correlated variables can be linked. The values and vectors, variance ratio, and contribution of each variable to each calculated component were calculated, and the variables that contributed significantly to the ecosystem were selected in the matrix that was obtained.

The most significant actions were ranked in order of importance based on the magnitude of the negative environmental impacts in accordance with the mathematical values obtained for the coefficients, which were transformed into percentages for ease of analysis. The results were classified according to the mathematical magnitude of the Spearman range coefficients that were closest to 1 . Spearman range coefficients with values between 0.700 and 1 were grouped in a first range or level of importance and coefficients with values 0.600 and 0.699 were included in a second range or level of importance (Table 3). Spearman range coefficients with values below these ranges were not considered due to the low relevance of the figures, although they are also present to a lesser degree in construction activities that cause environmental impacts.

The following main problems were detected from processing research data based on analyses of the development schemes and master plans of several tourism projects, existing environmental impact studies, the analysis of 54 projects, and in particular, statistical processing of construction activities in fragile coastal ecosystems that was validated by numerous field observations:

- To determine the main aspects to be considered in analyzing the negative and potential environmental impacts during the life cycle phases of tourist facilities (Table 4), it was seen that project design and technological and technical aspects caused most of the impacts.

- Therefore appropriate measures need to be taken to manage environmental impacts during the planning and projection stage and the execution of works to prevent, mitigate and correct many of the most severe impacts.

- During the construction phase, the principal activity that causes impacts is the opening of trails to allow passage of drilling equipment for engineering-geological studies. Technologies and practices with a low environmental impact need to be introduced to avoid these effects.

- During the operation phase, impacts are related to the number of tourists and workers due to high water and energy consumption, liquid and solid waste generation, social interactions and leisure and recreational activities in public areas.

- During the abandonment phase, environmental impacts relate to the presence of temporary facilities and the failure to restore the areas where they are located, as well as unused quarries and trails.

A total of 54 projects were reviewed and the following elements were obtained from the analysis:

- $80 \%$ of the projects were located in highly ecologically fragile ecosystems [12], of which $45 \%$ involved small islands or cays. The urban area of the entire tourism unit or sector was studied in only $13 \%$ of the cases. The synergy of the environmental impacts of nearby projects was not considered.

- $65 \%$ of the projects are villas and $74 \%$ are similar in their type and floor plan, regardless of the site or the natural landscape where they are located. There is a tendency to standardize tourism architecture.

- Only $12 \%$ of the projects reviewed included a technology transfer analysis of construction systems and other equipment for the implementation and operation phases. Only 8 projects had a detailed engineering and architectural assessment. The rest were limited to a brief description that did not analyze the technological impacts of the projects in the necessary depth.

- There was partial public participation and consultation in $19 \%$ of the environmental impact studies. Only $17 \%$ evaluated the impacts on cultural heritage. 
Table 2. Tourism projects selected for statistical processing in Cuba.

\begin{tabular}{|c|c|c|c|}
\hline & Project & Typology & Features \\
\hline 1. & Vials Coloradas & Vial & Located in Cays \\
\hline 2. & Golf Palma Real & Golf course & Located in Cays \\
\hline 3. & Punta Rasa & Beach restaurant & Located in Cays \\
\hline 4. & Gregorio & Villa resort & Located in Cays \\
\hline 5. & Las Terrazas & Villa resort & Located in Cays \\
\hline 6. & Punta Periquillo & Villa resort & Located in Cays \\
\hline 7. & La Laguna & Villa resort & Located in Cays \\
\hline 8. & El Manglar & Villa resort & Located in Cays \\
\hline 9. & Arena Real & Villa resort & Located in Cays \\
\hline 10. & Sol Club & Villa resort & Located in Cays \\
\hline 11. & El Peñón & Park & Located in Cays \\
\hline 12. & Cayo Сoco & Landfill & Located in Cays \\
\hline 13. & Coco Rojo & Villa resort & Located in Cays \\
\hline 14. & Coco II & Villa resort & Located in Cays \\
\hline 15. & SPA Thalasso & Health center SPA & Located in Cays \\
\hline 16. & Villa Blanca & Villa resort & Located in Cays \\
\hline 17. & Lindarena & Villa resort & Located in Cays \\
\hline 18. & Riu Tortuga & Villa resort & Located in Cays \\
\hline 19. & Villa Capricho & Villa resort & Located in Cays \\
\hline 20. & Pelícano II & Villa resort & Located in Cays \\
\hline 21. & Villa Iguana II & Villa resort & Located in Cays \\
\hline 22. & Arena Real & Beach restaurant & Located in Cays \\
\hline 23. & Vial Cuatro Caminos & Vial & Located in Cays \\
\hline 24. & Puerto Casasa & Port & Located in Cays \\
\hline 25. & Golf Varadero & Golf course & Located in Peninsula \\
\hline 26. & Varadero & Villa resort & Located in Peninsula \\
\hline 27. & Internacional I y II & Hotel & Located in Peninsula \\
\hline 28. & Internacional III & Hotel & Located in Peninsula \\
\hline 29. & Taínos III & Villa resort & Located in Peninsula \\
\hline 30. & Taínos IV & Villa resort & Located in Peninsula \\
\hline 31. & Taínos V & Villa resort & Located in Peninsula \\
\hline 32. & Taínos VI & Villa resort & Located in Peninsula \\
\hline 33. & Los Taínos & Villa resort & Located in Peninsula \\
\hline 34. & Viales Punta Hicacos & Vial & Located in Peninsula \\
\hline 35. & Hicacos & Villa resort & Located in Peninsula \\
\hline 36. & Reserva Varahicacos & Protected area & Located in Peninsula \\
\hline 37. & Piedra del Chino & Park & Located in Peninsula \\
\hline 38. & Hotel Kawama & Hotel & Located in Peninsula \\
\hline
\end{tabular}




\section{Continued}

\begin{tabular}{|c|c|c|c|}
\hline & Trinidad del Mar & Villa resort & Located in Peninsula \\
\hline 40. & María Aguilar & Villa resort & Located in Peninsula \\
\hline 41. & María La Gorda & Villa resort & Located in Peninsula \\
\hline 42. & Vial Los Morros & Vial & Located in Peninsula \\
\hline 43. & Cayo Blanco del Norte & Villa resort & Located in Peninsula \\
\hline 44. & Los Morros & Port & Located in Peninsula \\
\hline
\end{tabular}

45. Golf Club Golf course

46. Marina Hemingway

47. Río de Oro

48. Hotel Pasarela

49. Santa Lucia

50. Marina de Vita

51. Las Dalias

52. Playa Pesquero

53. Villa Megano

54. Covarrubia
Villa resort and marina

Villa resort

Villa resort

Villa resort

Villa resort and marina

Villa resort

Villa resort

Villa resort

Villa resort
Located in Mainland coastal ecosystems

Located in Mainland coastal ecosystems

Located in Mainland coastal ecosystems

Located in Mainland coastal ecosystems

Located in Mainland coastal ecosystems

Located in Mainland coastal ecosystems

Located in Mainland coastal ecosystems

Located in Mainland coastal ecosystems

Located in Mainland coastal ecosystems

Located in Mainland coastal ecosystems

\section{Table 3. Statistical information processing.}

\begin{tabular}{|c|c|c|}
\hline $\begin{array}{l}\text { Constructive actions that cause severe } \\
\text { environmental impacts on coastal ecosystems }\end{array}$ & $\begin{array}{l}\text { First range or level of importance } \\
\text { (values between } 0.700 \text { and } 1 \text { ) }\end{array}$ & $\begin{array}{l}\text { Second range or level of importance } \\
\text { (values between } 0.600 \text { and } 0.699 \text { ) }\end{array}$ \\
\hline \multicolumn{3}{|l|}{ Cays ecosystems } \\
\hline Excavation for deep foundations & 0.970 & \\
\hline Compaction of soils & 0.810 & \\
\hline Opening of trails with asphalt & 0.775 & \\
\hline High occupancy of land and naturall and scapes & 0.774 & \\
\hline Uniform design architecture (villas) & & 0.679 \\
\hline Extraction of raw materials & & 0.670 \\
\hline Foundations & & 0.611 \\
\hline \multicolumn{3}{|l|}{ Peninsula ecosystems } \\
\hline Seas and mining & 0.904 & \\
\hline Solid construction waste & 0.807 & \\
\hline Extraction of raw materials & 0.761 & \\
\hline Uniform design architecture (villas) & & 0.613 \\
\hline Temporary facilities & & 0.601 \\
\hline \multicolumn{3}{|l|}{ Mainland coastal ecosystems } \\
\hline High water consumption & 0.880 & \\
\hline High energy consumption & 0.802 & \\
\hline Air pollution & 0.705 & \\
\hline Noises & & 0.674 \\
\hline Solid construction waste & & 0.605 \\
\hline Extraction of raw materials & & 0.601 \\
\hline
\end{tabular}


Table 4. Potential environmental impacts during the life cycle phases of tourist facilities.

\begin{tabular}{|c|c|c|c|c|}
\hline $\begin{array}{l}\text { Construction activities in fragile } \\
\text { coastal ecosystems }\end{array}$ & $\begin{array}{l}\text { Planning and } \\
\text { projection phase }\end{array}$ & $\begin{array}{l}\text { Construction } \\
\text { phase }\end{array}$ & $\begin{array}{l}\text { Operation } \\
\text { phase }\end{array}$ & Abandonment phase \\
\hline $\begin{array}{l}\text { Trails to allow passage of drilling equipment } \\
\text { for geological studies }\end{array}$ & • & • & $\bullet$ & $\bullet$ \\
\hline Uniform design architecture (villas) & $\bullet$ & - & • & \\
\hline Temporary facilities & & $\bullet$ & $\bullet$ & $\bullet$ \\
\hline Compaction of soils & & - & $\bullet$ & \\
\hline High occupancy of land and naturall and scapes & & $\bullet$ & $\bullet$ & \\
\hline Air pollution & & • & $\bullet$ & \\
\hline Noises & & • & $\bullet$ & \\
\hline Excavation for deep foundations & & • & & \\
\hline Extraction of raw materials & & - & & \\
\hline Foundations & & - & & \\
\hline Seas and mining & & $\bullet$ & & \\
\hline Solid construction waste & & • & & \\
\hline Total & 2 & 12 & 7 & 2 \\
\hline
\end{tabular}

\section{Conclusions}

Similar technologies, materials and designs are used in all tourism projects, and in general, the architecture is poorly integrated with the cultural and natural image of natural coastal ecosystems. Tourism architecture appropriate for the exclusive cultural and natural values of these ecosystems should be found in order to avoid standardization and monotony in new areas of development.

The studies show that environmental impacts occur, which, in the future, will lead to a decrease in the available natural resources and consequently lower income due to resource depletion in sensitive coastal areas. The sources of non-natural or manmade (anthropogenic) environmental impacts are related to the purpose, location, type of construction and size of the projects, and determine the origin and development of the impacts caused by socio-economic activities.

The application of this methodology will help analyze the economic costs from an environmental standpoint of adopting preventive rather than remedial environmental measures, and economize on materials, labor, energy and time by focusing on the problem in advance and estimating the environmental costs that should be included in the long-term assessments of feasibility studies.

By delving into environmental assessment aspects and its relationship to the sustainable development of tourist facilities, the methodology suggests and defines actions to be undertaken to influence the development of tourist facilities according to sustainable approaches that contribute to improving the methodological approach and institutional and legal structures regarding the concepts and tasks of environmental regulatory activity.

The paper supports greater effectiveness in designing tourist facilities and considers environmental impacts in the process of prior analysis and decision making for planning, analysis of alternatives, selection of models, land use planning and design.

An analysis of information on investments on cays, peninsulas and in the mainland coastal ecosystems showed that the technological and technical aspects of direct construction activities above and below the ground (earthworks, filling, excavation, compaction and others) caused the greatest impact on fragile ecosystems, as well as the disposal of liquid and solid waste from construction. If the design and execution of these activities are properly managed, the impacts can be avoided or mitigated to a large extent.

\section{References}

[1] O’Reilly, V., Bancrofft, R. and Ruiz, L. (2010) Las tecnologías del concreto en su ciclo de vida. México. Concreto y Cemento: Investigación y Desarrollo. Revista CONPAT, 1, 42-47. 
[2] Utama, N.A., Ishihara, K.N., Tezuka, T., Zhang, Q. and Esteban, M. (2011) Transportation’s Impact Assessment on Construction Sector. Low Carbon Economy, 2, 152-158. http://dx.doi.org/10.4236/lce.2011.23019

[3] CIWMB (2000) Designing with Vision: A Technical Manual for Materials Choices in Sustainable Construction. California Integrated Waste Management Board, Sacramento, 113-131.

[4] UNWTO (2013) United Nations World Tourism Organization, Annual Report 2012. The World Tourism Organization (UNWTO), Madrid. http://mkt.unwto.org/publication/unwto-tourism-highlights-2013-edition

[5] Hall, C. and Stephen, J. (2014) The Geographic of Tourism and Recreation. 4th Edition, Routledge, Taylor \& Francis Group Ltd., London.

[6] Legrand, W., Claudia, S. and Philips, S. (2012) Sustainable Hospitality and Tourism as Motors for Development. Case Studies from Developing Regions of the World. Routledge, Taylor \& Francis Group Ltd., London.

[7] Edgell, L. and Jason, S. (2013) Tourism Policy and Planning Yesterday, Today, and Tomorrow. 2nd Edition, Routledge, Taylor \& Francis Group Ltd., London.

[8] Datta, R.K. (2008) Book: Mainland Coastal Ecosystems. Hazards, Management and Rehabilitation. Environmental Impacts of Tourism Development in Fragile Mainland Coastal Ecosystems, Operational Planning for Environmental Rehabilitation in Cuba. Daya Publishing House, India, 282-288.

[9] Wang, Y.T., Sun, M.X., Wang, R.Q. and Lou, F. (2014) Promoting Regional Sustainability by Eco-Province Construction in China: A Critical Assessment. Ecological Indicators, 51, 127-138. http://dx.doi.org/10.1016/j.ecolind.2014.07.003

[10] Lin, M.-C. and Teng, J.-Y. (2013) A Fuzzy Multicriteria Grade Cluster Analysis for the Budget Allocation of Tourism and Leisure Resources. American Journal of Industrial and Business Management, 3, 488-496. http://dx.doi.org/10.4236/ajibm.2013.35056

[11] De-Burgos-Jiménez, J., Vazquez-Brust, D.A. and Plaza-Úbeda, J.A. (2011) Adaptability, Entrepreneurship and Stakeholder Integration: Scenarios and Strategies for Environment and Vulnerability. Journal of Environmental Protection, 2, 1375-1387. http://dx.doi.org/10.4236/jep.2011.210160

[12] Alcolado, P.M., García, E.E. and Arellano-Acosta, M. (2007) Ecosistema Sabana-Camagüey: Estado, avances y desafíos en la protección y uso sostenible de la biodiversidad. Editorial Academia, Habana. 183 pp.

[13] Yu, H.G., Zhong, S.M. and Agarwal, R.P. (2010) Mathematics and Dynamic Analysis of Apparent Competition Community Model with Impulsive Effect. Mathematical and Computer Modelling, 52, 25-36. http://dx.doi.org/10.1016/j.mcm.2009.11.019

[14] Lourdes, R.G. (1999) La Evaluación de Impacto Ambiental de las Construcciones Turísticas en la Cayería Norte y otras zonas costeras de Cuba. Facultad de Arquitectura, ISPJAE. Tesis en opción al grado científico de Doctor en Ciencias Técnicas. La Habana, Cuba. 100 pp. 